\title{
現象論的モデルによる時空カオスの解析*
}

\author{
一一熱対流系を例として——
}

柳田達雄林

\section{Phenomenology for Convection}

\section{Tatsuo Yanagita}

\section{1. はじめに}

カオスの発見により時間的に不規則な振舞いを する多くの物理系が決定論的方程式にしたがって いることが明らかになった。しかし，通常，われ われが目にする現象は空間自由度を持つ大自由度 カオスであり，小数自由度カオスでは見られない 複雑な振舞いを示す。たと竞ば，熱対流現象は容 器の形状や Rayleigh 数等の変化にともない, 定 常状態から周期倍化・準周期運動・間欠運動など の複雑かつ多様なカオスへの分岐を示す的。また， 品間自由度を大きくすると，上に述べたようなき れいなカオスへの分岐現象は観湘されず，乱れた 状態が時間空間的に間欠的に現れ（時間空間間欠 運動) 乱流化する。さらに, Rayleigh 数が高い 乱流に搔いてもソフト・・ード乱流遷移現象が観 測されている2。

このような多様な振舞いも原理的には NavierStokes 万程式によって記述される。したがって， Navier-Stokes 方程式を正確に計算すれば現象 を定量的に再現することが可能である。しかし， 現象を再現することと現象の理解は必ずしも一致 しない。

熱対流のような複雑系に対しては定性的性質を 支配するダイナミクスを明らかにするのが理解へ の第一歩である。定性的性質は現象を記还する方 程式系の細部によらない普遍性を持つ。すなわち,
現象の定性的性質を再現するモデルは一つではな く，ある範囲のモデル族として存在する。したが って，モデルに多少の変更を加えても定性的性質 に影響はない。このような観点に立つと定性的性 質の説明には必ずしも Navier-Stokes 方程式を 基礎とする必要はない。

定性的解析を目的としたモデルを構築する場 合, カップルド・マップ・ラティスが有効であ る3。カップルド・マップ・ラティスは時間空間 を離散化し，連続変数である場の量からなる写像 力学系であり，物理現象を記述するモデルとして 広く用いられている(4) 。カップルド・マップ・ ラティスは短時間でシミュレーションができるた め, 多種多様な現象を調べられるほか，構成論的 にモデルのデザインができるため現象を支配して いるダイナミクスを明らかにすることができる。 この小論では，熱対流 (Rayleigh-Bénard) 系を 例にとり，その現象論的モデルを構築し，熱対流 のダイナミクスを理解することを試みる7)。

\section{2. 熱対流モデル}

カップルド・マップ・ラティスによるモデル化 は，離散化された格子上 $(x, y)$ に状態を記述す るための粗視化した場の量を選ぶことから始め る。ここでは, 熱対流の複雑かつ多様な振舞いを 表現するための最小限の場の量として温度 $E$, 速 度場 $\vec{v}$ を選んだ。モデルを簡単化するため圧力を ダイナミクスに直接に組み入れていないが，これ による物理的要因は写像によって間接的に取り入 
れられている。つぎに，これらの場の量が本質的 にどのような変換を受けて時間発展するかを考 え，それを $E ， \vec{v}$ に対する写像として表現する。 ここでは，対流のダイナミクスとして重要と思わ れる, 浮力, 熱抎散, 粘性, $\nabla \cdot \vec{v}=0$ を保つための 圧力の効果を考虑し，以下のよらな写像で表す。

\section{1. 浮 力}

温度が高いサイトは上昇する力を受ける。

$$
\begin{aligned}
v_{y}^{*}(x, y)= & v_{y}^{t}(x, y) \\
& +\frac{c}{2}\left\{2 E^{t}(x, y)-E^{t}(x+1, y)\right. \\
& \left.-E^{t}(x-1, y)\right\} \\
v_{x}^{*}(x, y)= & v_{x}^{t}(x, y)
\end{aligned}
$$

2. 熱桩散

熱拡散は離散化した Laplacian で表現する。

$$
E^{\prime}(x, y)=E^{t}(x, y)+\kappa \Delta E^{t}(x, y)
$$

ここで $\Delta$ は離散化した Laplace 演算子

$$
\begin{aligned}
& \Delta A(x, y)=\{A(x+1, y)+A(x-1, y) \\
+ & A(x, y+1)+A(x, y-1)-4 A(x, y)\} / 4
\end{aligned}
$$

である。

3. 粘性, 圧力効果

粘性は離散化された Laplace 演算子で表す。 また，非王縮性 $\nabla \cdot \vec{v}=0$ を表現するため $\nabla(\nabla \cdot \vec{v})$ を離散化したダイナミクスを導入した。この写像 は各格子上の発散 $\nabla \cdot \vec{v}$ を 0 にするように作用す る。 Navier-Stokes 方程式では非縮性の条件 は圧力場を計算し満足させるが，ここではこれを 行わず簡単な写像によって表した。

$$
\begin{aligned}
& v_{x}^{\prime}(x, y)=v_{x}^{*}(x, y)+\nu \Delta v_{x}^{*}(x, y) \\
+ & \eta\left\{\left(v_{x}^{*}(x+1, y)+v_{x}^{*}(x-1, y)\right) / 2\right. \\
- & v_{x}^{*}(x, y)+\left(v_{y}^{*}(x+1, y+1)\right. \\
+ & v_{y}^{*}(x-1, y-1)-v_{y}^{*}(x-1, y+1) \\
- & \left.\left.v_{y}^{*}(x 1, y-1)\right) / 4\right\} \\
y & \text { に関しても同様 }[x \leftrightarrow y]
\end{aligned}
$$

以上の手続きを逐次奏行した後，移流項 $((\vec{v} \cdot \nabla) \vec{v} ，(\vec{v} \cdot \nabla) E)$ を表現するための Lagrange 写像を導入する。各格子点上 $(x, y)$ に準粒子を考总，この準粓子はその格子点で の速度 $\vec{v}(x, y)$ にしたがい位置 $(x, y)+\vec{v}$ に移動し，場の量(ここではエネルギーEと 速度 $\vec{v}$ ) 運搬する。一般的に移動先は格子点 上ではないため，場の量は移動した点の四つ
の近接格子点に準粒子と近接格子点との距離に反 比例（てこの法則）させて分配する。

以上の写像を合成したダイナミクス

$$
\begin{aligned}
& \left\{\begin{array}{l}
\vec{v}^{t}(x, y) \\
E^{l}(x, y)
\end{array}\right\} \longmapsto\left\{\begin{array}{l}
\vec{v} *(x, y) \\
E^{t}(x, y)
\end{array}\right\} \\
& \longmapsto\left\{\begin{array}{l}
\vec{v}^{\prime}(x, y) \\
E^{\prime}(x, y)
\end{array}\right\} \stackrel{\text { Lagrangean }}{\longmapsto}\left\{\begin{array}{l}
\vec{v}^{t+1}(x, y) \\
E^{t+1}(x, y)
\end{array}\right\}
\end{aligned}
$$

によって，熱対流の時間発展を表す。

このモデルの基礎パラメーターは Rayleigh 数 に対応寸る上面と下面の温度差 $(\Delta E=E(x, 0)$ $\left.E\left(x, N_{y}\right)\right)$, Prandtl 数に対応する温度払散と粘性 率の比 $(\nu / \kappa)$, アスペクト数 $\left(N_{x} / N_{y}\right)$ である。 以下これらのパラメータを变化させたときの多様 な振舞いを実験と対比して述べてゆく。

3. シミュレーション

\section{1 カオスへの分岐}

カオスへの分肢現象はアスペクト此を小さくし 空間自由度を制限したときに観測され，Prandtl 数などによって異なったカオスへの道筋が選択さ れる゙っ。とえば，周期倍化からカオス状態とな る分肢は Prandtl 数が小さい場合に観測され9， Prandtl 数の大きい場合にはロールの準周期振動 (トーラス運動) からトーラスの崩壊によってカ オス状態となる ${ }^{10)}$ 。また， ロール数を制限するこ とによって，同じ Prandtl 数でも間欠運動から カオス化する場合もある11。

モデルに和いても Rayleigh 数に対応する $\Delta E$ の増加とともに熱伝導状態から対流状態へ転移す

る（図1に二次元モデルのベクトル場を示した）。 また，複雑かつ多様なカオスへの分岐現象を再 現し，分岐の Prandtl 数依存性も実験結果と定 性的に一致する。例として，準周期運動の低周波

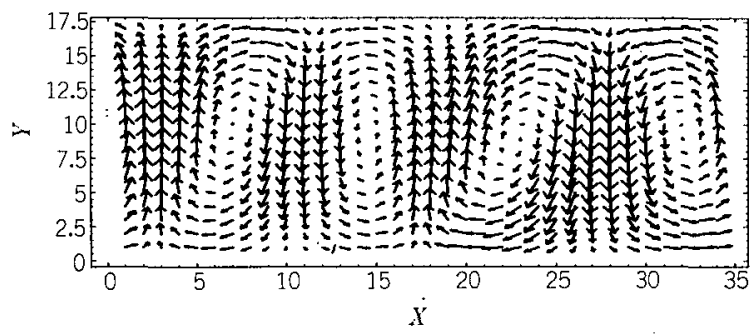

2 次元モデルのベクトル場。ロールが形成されていることが分か る。 $N_{x}=34, N_{y}=17, \kappa=0.4, \nu=\eta=0.2, \Delta E=0.5$

図12 次元ベクトル場 


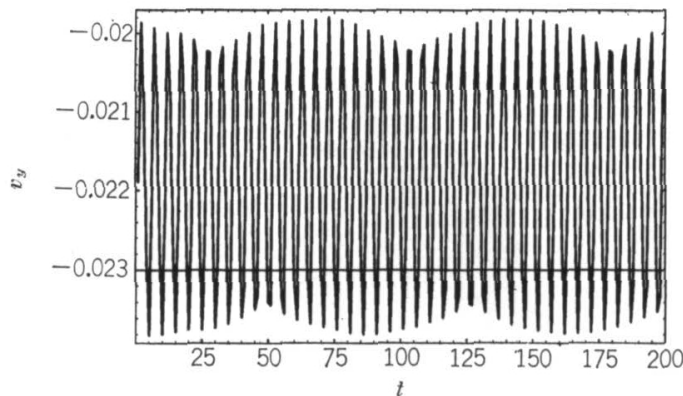

(a)

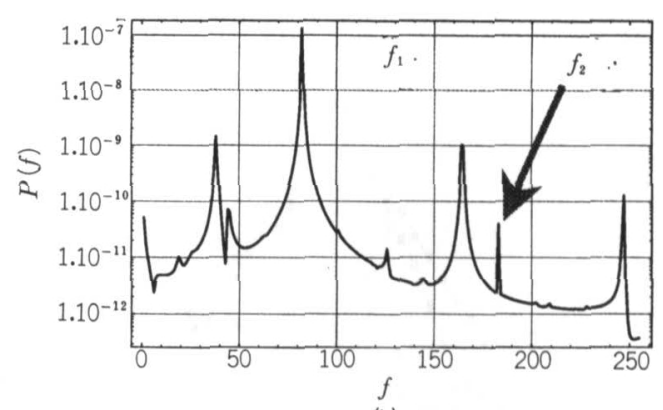

(b)

Prandt1 数が大きい場合 $\kappa=0.002, \mu=0.2$, ロールが周期 $f_{1}$ で振動し, $\Delta E$ の増加とともに $f_{1}$ とは独立な周期 $f_{2}$ が出現し 準周期運動を行う。この例では, $f_{1}$ が周期倍化を起こし (トーラス倍化) $f_{1} / 2$ の周期が観測されている。(a) $\Delta E=0.5$ での中 心点 $\left(N_{x} / 2, N_{y} / 2\right)$ での速度の鉛直成分 $v_{y}$ の時間変化。(b)時間変化のパワースペクトラム

図 2 準周期運動

数の振動が周期倍化を起こしてカオス状態となる トーラス倍化を図 2 に示す。

\section{2 時間空間間欠運動}

アスペクト比を増加させ多数のロールがある系 では上述したカオスへの道筋は見られず, 乱れた 運動が時間空間的に間欠的に現れる運動（時間空 間間欠運動）が観測される(図 3)。この運動は 空間的に拡がりを持つ系が乱れる時に見られる普 遍的現象であり, 層流状態が続く空間的長さの確 率分布によって特徵づけられる ${ }^{12), 13)}$ 。特に, 時間 空間間欠運動の開始点ではベキ分布を示し，その ベキも実験と一致する7)。

\section{3 乱流遷移}

$\Delta E$ を增加させるにしたがいプリュームが生じ 始め空間的に乱れた構造となる（図 4)。この乱 流状態は中心点での温度の分布関数によって特徴 づけられ, Rayleigh 数の増加にともない分布は

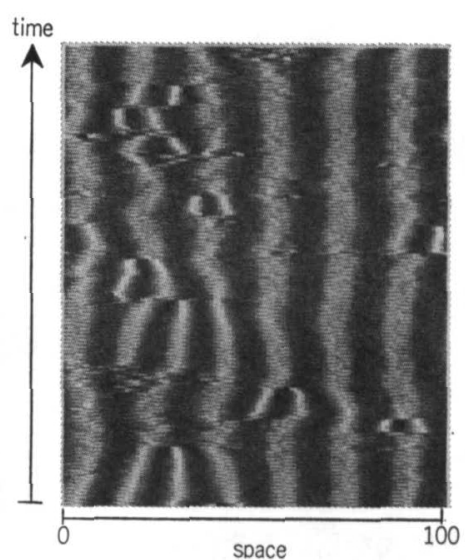

2 次元モデルの $y=N_{y} / 2$ 断面に特ける $v_{y}$ の時間変化。白 は上昇流を黒は下降流を表す。時間空間的に乱れが生じて いることが分かる。

図 3 時間空間間欠運動

ガウス型から指数型へと変化する2゙。われわれの モデルに拈いても，このソフト・ハード遷移を再

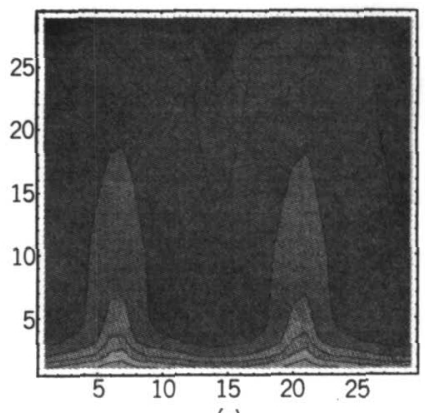

(a)

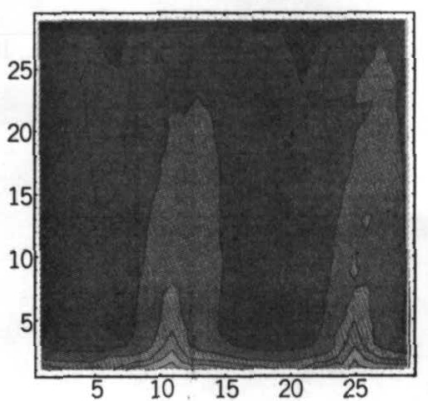

(b)

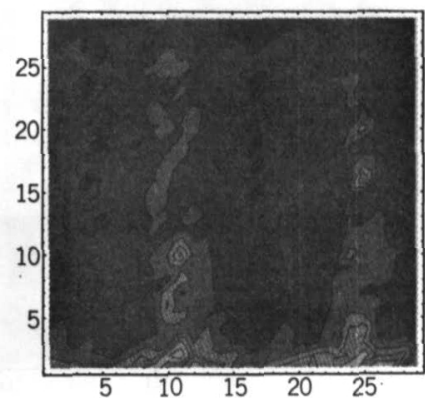

(c)

$\Delta E$ の増加にともないプリュームが発生し乱流化する。(a) $\Delta E=1.0$ 対流状態 $\quad$ (b) $\Delta E=3.0$ ソフト乱流 $\quad$ (c) $\Delta E=10$ ハード乱流 図 $4 \Delta E$ の增加に伴う温度場の変化 


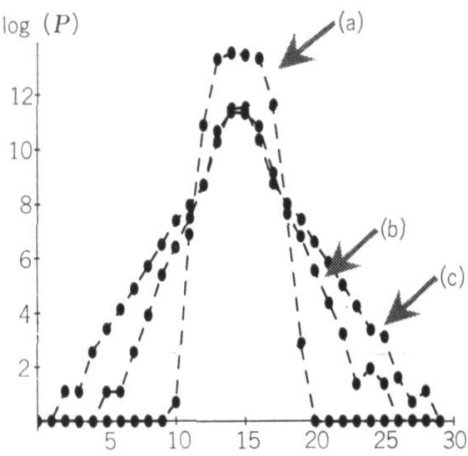

中心点 $\left(N_{x} / 2, N_{y} / 2\right)$ で観測した温度の分布関数。 $\Delta E$ の 増加にともない温度分布はガウス型分布 (a) $\Delta E=3.0$ から 指数型(b)(c) $\Delta E=5.0,10.0$ 亿遷移をし, 実験事実とよく 一致する。

図 5 ソフトーハード乱流遷移

現し（図 5)，分布の違いはプリニームが反対側 の境界まで到達することができるかどらかに関係 していることが分かる。さらに，分布をフラット ネス $\left\langle(E-\langle E\rangle)^{4} /\left\langle(E-\langle E\rangle)^{2}\right\rangle^{2}\right.$ により特 徵づけ，そのPrandtl 数依存性を調べた(図 6)。 Prandtl 数が低い系ではフラットネスは $3 \sim 6$ ま で変化し, ガウス型から指数型への遷移を明確に 表している。これに対し, 高 Prandtl 数では 6 を越 え11程度まで増加することが分かる。このような 広範囲にわたるパラメータ空間の探索は NavierStokes 方程式を用いた数值解析では困難である。

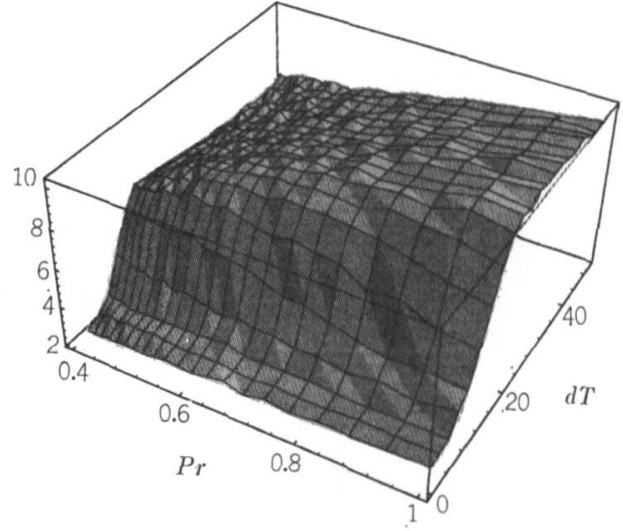

温度の分布関数の Prandtl 数依存性をフラットネスによ って特徵づけた。Prandtl 数が低い場合にはフラットネス は3.0〜6.0まで変化し，ガウス型から指数型に遷移するこ とがわかる。Prandtl 数が高い場合には 6.0 を越え 11.0 ま で増加することが分かる。

図 6 温度分布の Prandtl 数依存性

\section{4 パターン形成}

モデルの三次元への拡張は容易で，パターン形 成，パターン競合によるカオス，欠陥カオス，さ らに乱流への変化等を調べることができる。三次 元モデルの空間パターンの時間変化を図 7 に示 す。パターン形成の初期段階では短時間内に大域 的構造が形成されるが，ロール欠陥の消滅には非 常に長時間の時間発展を必要とする。このような 空間構造の時間発展も実験結果とよく一致する。
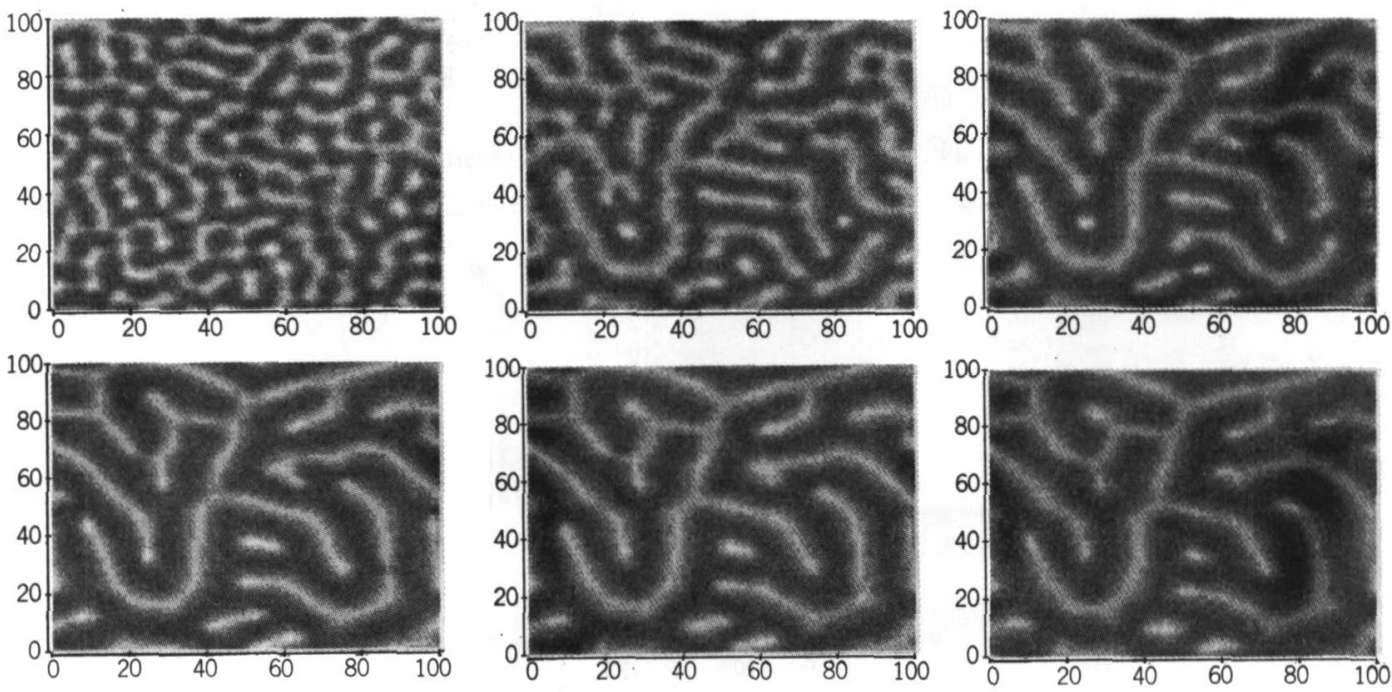

$z=N_{z} / 2$ での断面での鈶直速度成分の時間発展。 $\Delta E=1.0$ で300ステップごとのスナップショット。始めに大域的構造が作られ， 欠宿の消滅には長時間の時間発展が必要であることが分かる。

図 7 パターン形成 


\section{4.まとめ}

ここで紹介した熱詨流モデルは周期倍化，準周 期運動などの多様なカオスへの分岐現象，時間空 間間欠運動,ソフト・ハード乱流遷移, パターン形 成などの幅広い現象を再現し，Prandtl 数依存性 や統計的特徴も定性的によく一致する。NavierStokes 方程式を基礎とした数値解析では広範团 にわたるパラメータ空間の探索は困難である。こ のため，現象の大域的棰造を調べるためには定性 的モデルによる解析が有用である。

現象の定性的振舞いはモデルの細部によらない 普㴜性を持つ。たと壳ば，乱流僄移現象に括ける 分布の遷移はプリュームの性質の反映であり，七 デルの詳細によっていない。したがって，定性的 性質を支配しているダイナミクスを理解するに は，どのようなモデルの範网ならばその定性的性 質を再現することができるかを明らかにすること である。言い換光れば，現実を再現するモデルと 再現しないモデルの境界(虚実境界)を明らかにす ることである。カップルド・マップ・ラティスは 個々の要素を一つの写像として表しているため, 要素を取り除いたり，変化させたりと構成的に二 デルを構築でき虚契境界を探索する方法として有 效である。

われわれの視覚は動的な振舞いの性質を捉える のに優れた能力を持っている。したがって，動的 な性質を解析するために現象の可視化は重要な要 素である。カップルド・マップ・ラティスは短時 間の演算で時間発展するため, その勒的な振舞い をワークステーションで観測できる。したがっ
て，熱詨流系のみならず複雑な現象の動的・定性 的性質を理解するために強力な方法である。たと えば，相転移現象を伴ら沸滕到や雲のダイナミク スまたシアーフローや Kármán 渦とそれらの 崩壊に伴ら乱れの空間的伝達機構の解析に有効と 思われる。

\section{参考文献}

1) P. Manneville: Dissipative Structure and Weak Turbulence, Academic Press, 1990.

2) M. Sano, X. Z. Wu A. Libchaber: Phys. Rev. A, $40: 6421,1989$.

3) K. Kaneko: Collapse of Tori and Genesis of Chaos in Dissipative Systems, World Scientific, 1983.

4) K. Kaneko: Simulating Physics with Coupled Map Lattice, volume 1 of Formation, Dynamics and Statistics of Patterns, World Scientific, 1990.

5) Y. Oono, S. Puri : Study of phase-separation dynamics by use of cell dynamical systems, 1. modeling, Phys. Rev., 38A : 434, 1988.

6) T. Yanagita : Phenomenology for boiling: A coupled map lattice model, Chaos, 3-2: 343, 1992.

7) T. Yanagita, K. Kaneko: Coupled map lattice model for convection, Phys. Lett., 175A : 415-420, 1993.

8) A. Libchaber, J. Maurer: A Rayleigh-Bénard experiment: Helium in a small box, In T. Riste, editor, Nonlinear phenomena at phase transitions and instabilities, page 259. Plenum Pub., 1982.

9) J. Maurer, A. Libchaber: $J$. de Physique Colloques, 41-C3 : 51, 1980.

10) M. Dubois, P. Bergé : J. Physique Letters, 42: 167, 1981.

11) J. P. Gollub, S. V. Benson : Many routes to turbulent convection: J. Fluid Mech., 100: 449-470, 1980.

12) S. Ciliberto, P. Bigazzi: Spatiotemporal intermittency in Rayleigh-Bénard convection, Phys. Rev. Lett., $60: 286,1988$.

13) F. Daviadu, M. Bonetti, M. Dubois: Transition to turbulence via spatiotemporal intermittency in onedimensional Rayleigh-Bénard convection, Phys. Rev. A, 42-6: 3388, 1990. 


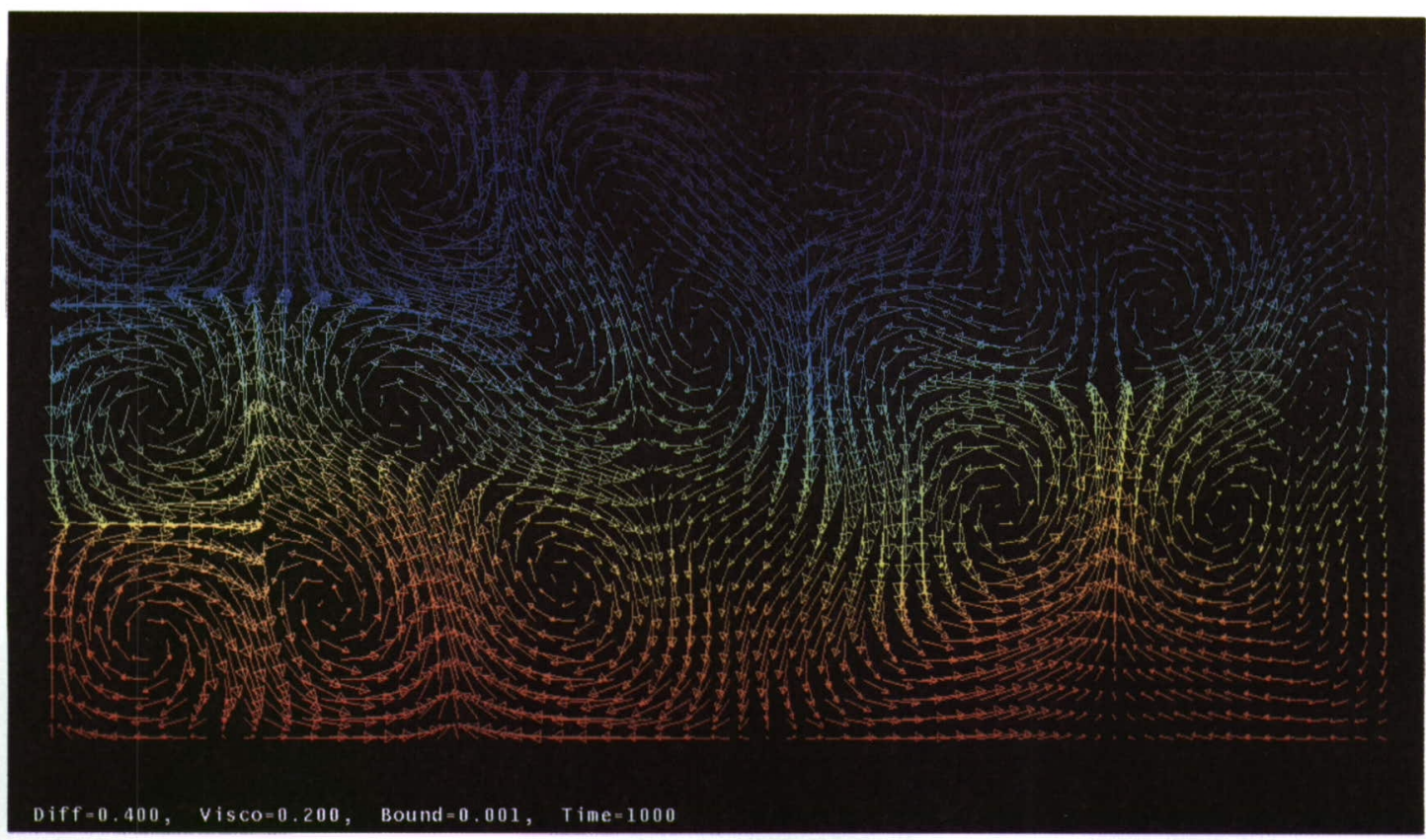

口絵1 2 次元ベクトル場（東京工業大学 柳田達雄）

(本文149頁参照)

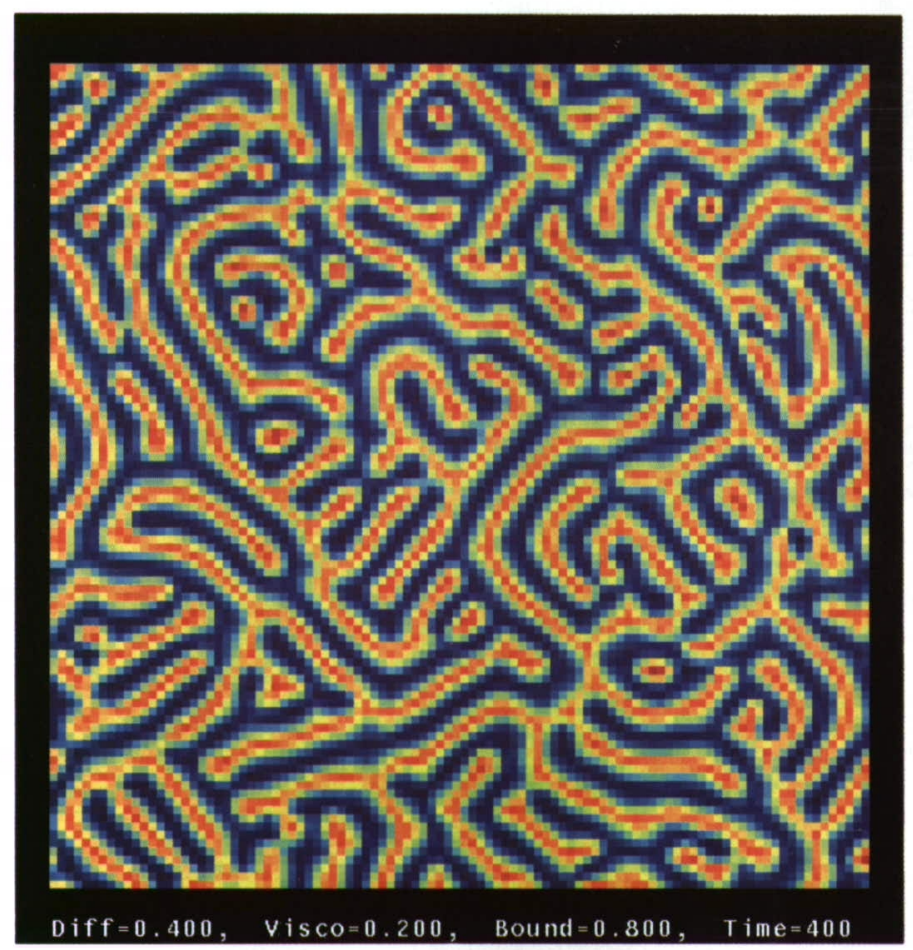

口絵2 3次元モデルの空間パターン (東京工業大学 柳田達雄)

(本文149頁参照) 